\title{
Teaching Translation through STAD (Students Team Achievement Division) Technique
}

\author{
Rahmawati Upa' ${ }^{1}$, Muhammad Resqi Ridho ${ }^{2}$ \\ 1,2 Universitas Cokroaminoto Palopo \\ ${ }^{1}$ rahmawatiupa22@gmail.com, ${ }^{2}$ mresqiridha@gmail.com
}

\begin{abstract}
This research aims at finding out whether or not the use of STAD technique in teaching translation is effective to improve students' translation ability at English Education Program, Faculty of Teacher Training and Education. The population in this research was fifth semester students in academic year 2019. The researchers use pre-experimental method with pre-test and post-test design, and translation test as instrument of this research. Then the researchers analysed the data by using Statistical Product and Service Solution (SPSS) program. The researchers conclude that using Students Team Achievement Division (STAD) technique to teach translation in the fifth semester students of English Education Program is effective. It is proven by mean score of the students in the post-test $(80.20$ (good)) is higher than mean score of students in the pre-test $(68.87$ (fairly good)). The researchers also found that the $p$ value $(0.00)$ on t-test is lower than $\alpha$ (0.05). It indicates that the alternative hypothesis $\left(\mathrm{H}_{1}\right)$ is accepted and the null hypothesis $\left(\mathrm{H}_{0}\right)$ is rejected. It can be concluded that teaching by using STAD technique is effective in improving students' ability in translation.
\end{abstract}

Keywords: translation, STAD

\section{Introduction}

One of the most important things in mastering second language is translation because without knowing translation, it is difficult to understand the meaning of source language to target language. Translation subject is one of the major courses in English Language Education Study Program of Cokroaminoto Palopo University, which is learned by the students in the third semester. From that subject the students are expected to be able to translate from source language to target language correctly, but in case the fact which is happening in student daily life is different. The student prefer to use translator machine as tools to translate and it makes the students have low quality in translating because now day, we can find translator machine easily such as, offline dictionaries or Google Translate so they prefer to use that tools because it is more efficient and easier than translating manually.

Hatim and Munday (2004) also suggest that "one of the key problems for the analysis was in actually determining whether the source text meaning had been transferred into the target text". Although students may have a good understanding of English, reading translation theory, they sometimes still make mistakes in translating English text into Indonesian.

Based on this problem, the researchers decide to use Student Team Achievement Division (STAD) technique in teaching translation as solution for the problem. This research is conducted in order to find out whether or not the use of STAD is effective in teaching translation. STAD is used due to this method is able to increase the student participation in 
learning translation. Cruickshank, Jenkins and Metcalf (2006) stated that STAD has advantages and disadvantages. The advantages are, encourage learners to work together for both the common and individual good, make students feel better to themselves and to more accepting of other. Students will have an equal opportunity to learn. Students with lower abilities are more likely to improve their achievement in mixed group. Students will be active in teaching learning process.

\section{Related Literature}

Brislin (2010) states that translation is a general term referring to the transfer of thoughts and ideas from one language (source) to another (target), whether the language is in written or oral form. Bell (2011) assumes that translation is the expression in another language (target language) of what has been expressed in one, source language, preserving semantic and stylistic equivalences. He also views that translation involves the rendering of a source language text into the target language, so as to ensure that the meaning of the two will approximately similar, and the structure of the SL will be preserved as closely as possible, but not so closely that target language structure will be seriously distorted. Referring to this research, translation here is the process of transferring ideas from English into Indonesia in the written form.

Gross (1991) stated that STAD is the method in teaching learning process that is effective to increase student motivation and enthusiasm, and it can develop their responsibility in their own group. It is considered a good model because as one the CL strategy. It can raise student's motivation in learning by exchanging and sharing information, reinforcing each other, giving feedback and having the responsibility for their task in group work.

Slavin (2010) stated that in Student Team Achievement Division (STAD) Technique students are grouped into learning teams with diverse member of ability, gender, race, and ethnicity. In placing student in team do not let students choose their own team. The teacher presents the lesson and the student work together in team to make sure all members have finished the lesson well. At last all the students get individual quiz about teaching material and at that time each individual cannot be mutually. Then, the reward which is given is team reward. STAD is prevailing and simple method in cooperative learning that consist of five major components; class presentations, team, quizzes, individual improvement scores, and team recognition.

According to Suprijono (2013), there are some steps in implementing Students' Team Achievement Divisions (STAD) are: 1) Form groups of 4-5 students in heterogeneous members (mix according to achievement, gender, ethnicity, etc.), 2) Teachers present the lessons 3) Teacher gives a task to the group and it will be answered by members of the group. Members who already understand can explain to other members until all members understand, 4) Teacher gives a quiz or question to all students. When answering the quiz, the students should not help each other out, 5) Giving the evaluation, 6) Conclusions.

\section{Method}

This research is a pre-experimental research with one pre-test and post-test which was conducted in August 2019 to September 2019. In determining the sample, the researchers applied purposive sampling technique by choosing the fifth semester students of English Education Study Program in Cokroaminoto Palopo University who had finished translation subject and it is restricted for fifteen until twenty students and it is chosen based on the students final score in translation subject before. The instrument used was translation test. 
The students were ordered to translate an English News into Indonesia. In conducting the research, there were three procedures done by the researchers, they were Pre-test, treatment (4 meetings) and post-test and the data was analyzed trough SPSS version 20.

\section{Results \& Discussion}

Table 1. Students' score in pre-test and post-test

\begin{tabular}{lllllll}
\hline \multirow{2}{*}{ No } & Classification & Score & Pre-Test & Post-Test & \\
\cline { 4 - 7 } & & Frequency & $\begin{array}{l}\text { Percentage } \\
(\%)\end{array}$ & Frequency & $\begin{array}{l}\text { Percentage } \\
(\%)\end{array}$ \\
\hline 1 & Excellent & $96-100$ & 0 & 0 & 0 & 0 \\
2 & Very good & $86-95$ & 0 & 0 & 4 & 27 \\
3 & Good & $76-85$ & 5 & 33 & 7 & 47 \\
4 & Fairly good & $66-75$ & 4 & 27 & 4 & 27 \\
5 & Fair & $56-65$ & 6 & 40 & 0 & 0 \\
6 & Poor & $36-55$ & 0 & 0 & 0 & 0 \\
7 & Very poor & $0-35$ & 0 & 0 & 0 & 0 \\
\hline
\end{tabular}

Table 2. The mean score and standard deviation of pre-test and post-test

\begin{tabular}{lll}
\hline Types of Test & Mean Score & Standard Deviation \\
\hline Pretest & 68.87 & 7.58 \\
Posttest & 80.20 & 7.24 \\
\hline
\end{tabular}

By referring the table above, that shows the mean score and standard deviation, it can be seen that, there is the difference of mean score between pre-test and post-test, where the mean score of the post-test is greater the mean score of the pre-test $(80,20>68,87)$. Standard deviation in the pre-test is 7.58, while in the post-test it is 7.24. The researcher uses Statistical Package for Social Science (SPSS) to know the mean score and the standard deviation of the research. It shows that there is the difference between pre-test and post-test. It can be stated that teaching translation specifically in phrases mastery by using STAD technique was able to improve students' ability in translation.

Table 3. Test of Normality

\begin{tabular}{lllllll}
\hline \multicolumn{1}{l}{ Tests of Normality } \\
& \multicolumn{1}{l}{ Kolmogorov-Smirnov ${ }^{\mathrm{a}}$} & \multicolumn{3}{l}{ Shapiro-Wilk } \\
\cline { 2 - 7 } & Statistic & Df & Sig. & Statistic & Df & Sig. \\
\hline Pretest & .191 & 15 & .146 & .885 & 15 & .056 \\
Posttest & .222 & 15 & .044 & .890 & 15 & .066 \\
\hline a. Lilliefors Significance Correction & & & & \\
\hline
\end{tabular}

From the table it can be seen that the significance of the test of normality the first is pretest that is 0.056 and post-test is 0.066 and the hypothesis of test of normality is:

HO: the data is distributed normally

Ha: the data is not distributed normally

$\mathrm{HO}$ is accepted if the score of $>a=0.05$, and it means the data is distributed normally. $\mathrm{Ha}$ is accepted if the score of $\angle \alpha=0.05$ and it means the data is not distributed normally (Ghozali, 2016). From the data above the researcher concludes that pre-test (0.056) and post-test (0.066) are bigger than 0.05 and the data is distributed normally and $\mathrm{HO}$ is accepted. 
Table 4. Paired Sample Test

\begin{tabular}{|c|c|c|c|c|c|c|c|c|c|}
\hline \multicolumn{10}{|c|}{ Paired Samples Test } \\
\hline & & \multicolumn{5}{|c|}{ Paired Differences } & \multirow[t]{3}{*}{$t$} & \multirow[t]{3}{*}{ df } & \multirow{3}{*}{$\begin{array}{l}\text { Sig. } \\
\text { (2- } \\
\text { tailed) }\end{array}$} \\
\hline & & \multirow[t]{2}{*}{ Mean } & \multirow[t]{2}{*}{$\begin{array}{l}\text { Std. } \\
\text { Deviation }\end{array}$} & \multirow[t]{2}{*}{$\begin{array}{l}\text { Std. Error } \\
\text { Mean }\end{array}$} & \multicolumn{2}{|c|}{$\begin{array}{l}95 \% \text { Confidence Interval of the } \\
\text { Difference }\end{array}$} & & & \\
\hline & & & & & Lower & Upper & & & \\
\hline $\begin{array}{l}\text { Pair } \\
1\end{array}$ & $\begin{array}{l}\text { Pretest - } \\
\text { Posttest }\end{array}$ & $\begin{array}{l}- \\
11.333 \\
33\end{array}$ & 5.65264 & 1.45951 & -14.46366 & -8.20300 & $\begin{array}{l}- \\
7.7 \\
65\end{array}$ & 14 & .000 \\
\hline
\end{tabular}

The hypothesis of test of significance is, there is significant if pvalue $<0.005$ (Ghozali, 2016). From the table above it can be seen that $p$ value is 0.000 and the researcher concludes that there is significant of this research.

While the Hypotheses of this research are:

$\mathrm{H}_{0} \quad=\quad$ There is no significant difference in student phrases mastery after being taught by using STAD method before and after treatment.

$\mathrm{H}_{1}=$ There is significant difference in student phrases mastery after being taught by using STAD method before and after treatment.

From, the hypothesis above the researcher concludes that, $\mathrm{H}_{1}$ is accepted because there is significant difference in student phrases mastery after being taught by using STAD method before and after treatment.

In research process the first the researcher gave translation test to the students in the pretest. It is about translating the English news into Indonesia. After giving the pre-test the researcher continues to give the students the treatment. In the treatment phase the researcher was teaching about phrases, those were, noun phrase, adjective phrase, adverbial phrase, prepositional phrase and verb phrases. The researcher explained the definition of each phrase to make the students were able to distinguish the kind of every phrases easily. After giving the definition of every phrase, the researcher explained about the form or pattern of every phrase and gave the example about it. After getting the explanation the students were ordered to do group discussion about the phrase that had been explained. Overall the students can understand the lesson well. After doing treatment phase the researcher continued to give post-test to the students to know the effectiveness of the method that was used before in teaching and learning process.

In process of learning translation, the researcher found that the students were totally enthusiasm and pay attention well to the learning material. They did the discussion in their group and sometimes ask to the researcher about the lesson which they had not understood yet. It supports the theory proposed by Cruickshank, Jenkins and Metcalf (2006) they stated that STAD, encourage learners to work together for both common and individual good to make students feel better to themselves and to more accepting of other. Students will have an equal opportunity to learn. Students with lower abilities are more likely to improve their achievement in mixed group. Students will be active in teaching learning process. Beside got the explanation from the researcher the students also got additional knowledge about phrases when actively do the discussion in their group. The students will understand the lesson easily when they share and ask to each other. There were no students felt under pressed because they have known and close one another. Good relation makes them, enjoy the learning process and create good atmosphere in the classroom. The researcher also found that most 
of the students understood the lesson easily, because at the end of the meeting the researcher gave the evaluation to the classmates and it was done individually.

Thus, the researcher concludes that, teaching translation specifically phrases mastery by using STAD technique is effective to improve the student' translation ability. For additional comparison the researcher refers to other research about STAD technique which has similar result with this research. Padang (2014), in his research "Developing English Vocabulary by Using Student Team Achievement Division Method at the First year students of SMK Analisis Mandala Bhakti Palopo" he concludes that by using STAD Method there is significant effective in developing students vocabulary. It is proven by the result of the test where $t_{0}$ was higher than $t_{t}(10.89>2.09)$. While, Nurjaenah (2014), in her research "The Implementation of Collaborative Writing: Peer Assisted Writing Activity to increase the Students' Writing Skill at the First Year Students of SMA Negeri 4 Palopo also found similar result, there were significant between students' mean score in pre-test and post-test. In this research the researcher applied STAD method in writing activity. In this research the researchers applied STAD technique in teaching phrase to improve students' translation ability.

\section{Conclusion}

Based on the result at findings above, the researcher concludes that teaching translation trough STAD technique is effective to improve the students' translation ability.It is proven by mean score of the students in the post-test $(80.20$ (good)) is higher than mean score of students in the pre-test (68.87 (fairly good)). The researcher recommends STAD technique to be applied in teaching and learning translation process. This technique is one of appropriate method to improve the students' ability in translation specifically in phrases mastery. This technique is able to increase the student participation during the process of teaching and learning in the classroom. Sharing and discussing to each other in the group, is the key to get successful learning in the classroom.

\section{References}

Bell. (2011). A Framework for Translation Evaluation and Practice.Translation Studies Journal, 3(9), 75-86.

Brislin. (2010). Application of Lexical-Functional Theory in Designing an English-Persian Translation Machine. Literary Criticism Journal, 6(21), 25-47.

Cruickshank, D. R., Deborah, J., \& Kim, K. M. (2006). The act of teaching. New York: McGraw Hills.

Ghozali, I. (2016). Aplikasi Analisis Multivariate Dengan Program IBM SPSS 25 Edisi 9. Semarang: Badan penerbit Universitas Diponegoro.

Gross, P. (1991). Teaching Learning Activity for Students at Senior High School. London: Harper Collins Publisher.

Hatim \& Munday. (2004). Translation: An Advanced Resource Book. London: Routledge. Nurjaenah. (2014). Developing English Vocabulary by Using Student Team Achievement Division (STAD) Method at the First Year Student of SMA Negeri 4 Palopo. Unpublished thesis Palopo. Palopo: Faculty of Teacher Training and EducationUniversitas Cokroaminoto Palopo

Padang. (2014). Developing English Vocabulary by Using Student Team Achievement Division (STAD Method at the first year Student of SMK Analisis Mandala Bhakti Palopo. Unpublished thesis Palopo: Faculty of Teacher Training and Education-Universitas Cokroaminoto Palopo 
Slavin, R. E. (2010). Cooperative Learning Teori Riset dan Praktek. Bandung: Nusa Media.

Suprijono, A. (2013). Cooperative Learning. Teori dan Aplikasi Pakem. Yogyakarta: Pustaka Pelajar. 